\title{
INFLECTION OF MODERN ICELANDIC NOUNS, ADJECTIVES AND ADVERBS
}

Summary. The present paper is a list of Modern Icelandic nouns, adjectives, and adverbs, analysed into their respective stems and endings; the declension of the suffixed definite article is also included. Under each item it is stated which phonological rules, if any, apply in the derivation of its grammatical forms. The following items of the list should be consulted for new phonological rules: (3), (11), (12), and (133). A grammatical innovation has been implemented in the list, namely the so-called REPLACING ENDINGS. These are not added after the last segment of the stem, as endings usually are, but replace the last segment(s) of the stem. More is said on replacing endings in the Introduction. ${ }^{1}$

Introduction. The list below contains the analyses of a number of Modern Icelandic nouns, adjectives, and adverbs into their respective stems and endings. There are two main reasons for releasing this list: (a) Such analyses have not been published before. (b) As matters stand now, the division of labour between the morphological and phonological components of grammar is to a considerable extent arbitrary; it is therefore necessary to state explicitly what the researcher relegates into the one, and what into the other component.

The lexical items treated in the list have been culled from the handbooks, notably from Einarsson 1945. While the list is not exhaustive, it is hopefully representative. In not a few cases it has been necessary to adduce alternative analyses of the same data; such analyses are indicated by small Latin characters, (a), (b), (c), ... Some ending morphemes display more than one morph; such allomorphs are separated by and. In some instances I could not decide on just one representation of a desinence morph; the sundry possibilities listed are separated from each other by or.

One characteristic of the list below is that it postulates quite a great deal of stem suppletion in Modern Icelandic paradigms. A problem in this connection was how to state the distribution of the suppletive stems, notably which stem occurs "elsewhere". In such cases I have endeavoured to make that stem occur "elsewhere" which is used in the nominative singular (the positive in the case of the adverbs): the "elsewhere" stem is the least marked stem variant, and the nominative singular (the positive of adverbs) is the least marked form.

In each entry it is stated which morphological and phonological rules apply in the derivations of its sundry case forms. In a few cases the pertinent rules have so far not been formulated; some are therefore given here for the first time; some are left unstated. The list is an indicator of the work that remains to be done. Here I especially mention the quantity rules; their formulation is a task for future research. 
Some readers may be astonished to see that I posit no ending, say, in the gen. sg. koss of koss "kiss" (see no. (7) in the list). I have strictly adhered to the phonetic facts and followed, wherever applicable, that principle of analysis which states that the boundary between the stem and the ending is identical to the boundary between SAME and DIFFERENT in the members of the paradigm. Whoever wishes to posit, say, / $/ \mathrm{koss}^{+} \mathrm{s} /$ as the phonological representation of the gen. sg. koss has to find sufficient motivation for his solution. The principle that the number of ending allomorphs should be kept to a minimum has so far not been proved valid, and therefore is not sufficient motivation for the representation / $/$ oss $+\mathrm{s} /$.

As for the first time in Orešnik 1973, I here distinguish two kinds of endings, ADDED and REPLACING. Those endings are added which are placed immediately after the last segment of the stem. E. g. in the gen. sg. bord-s of bord "table", -s is an added ending. Those endings are replacing whose initial segment replaces the last segment(s) of the stem. E.g. in the strong dat. sg. f. storri of Old Icelandic stórr "big, great", -rri is a replacing ending: its initial segment replaces the final segment $\underline{r}$ of the stem stor-. I indicate the segment(s) to be replaced by the initial segment of a replacing ending by an opening round bracket to the left of the segment(s) to be replaced: /stó(r+r:I/. The representation /stó$(\mathrm{r}+\mathrm{r}: \mathrm{I} / \mathrm{is}$ morphological; the corresponding underlying phonological representation is /stór:I/. An ending may be added in one form, replacing in another. E. g. -rri is added in the Old Icelandic strong dat. sg. f. ny-rri of nýr "new", and replacing in stórri. Both the addition of the endings and their replacement, in the manner indicated, are morphological processes. In particular, the replacement of the last segment(s) of the stem by the inital segment of the replacing ending can be characterised as consonantal ablaut. Thus $\underline{\mathrm{r}} \sim \underline{\mathrm{rr}}$ in stór-vs. stórri is an instance of consonantal ablaut.

The following example couched in terms of language acquisition illustrates how replacing endings are thought to come into being. Given the morphological representation /havts/ of the gen. sg. hafs (of haf "sea"), and given the corresponding systematic phonetic representation [hafs], the language learner is assigned the task of finding a derivation leading from /havts/ to [hafs]. One way of solving this problem is to posit a rule which devoices $/ v /$ to $/ f /$ before $/ \mathrm{s} /$. Another way is to manipulate the morphological representation by changing its ending as follows. In the representation /hav $+\mathrm{s} /$ the ending $/+\mathrm{s} /$ corresponds to the last segment of the representation [hafs]. The change of the underlying ending consists in adding yet another segment of [hafs] to $/+\mathrm{s} /$. This results in $/ \mathrm{fs} /$ and in the morphological representation $/ \mathrm{hav}+\mathrm{fs} /$. Since there is no rule in the grammar deleting $/ \mathrm{v} /$ before $/ \mathrm{f} /$, this ending becomes replacing, $/ \mathrm{ha}(\mathrm{v}+$ $+\mathrm{fs} /$. The phonological representation is now $/ \mathrm{hafs} /$, and the derivation leads to [hafs].

As the example hafs shows, replacing endings are a systematic rule saving device: by positing $/ \mathrm{ha}(\mathrm{v}+\mathrm{fs} /$ the need for a rule (the one devoicing $/ \mathrm{v} /$ ) is eliminated. Replacing endings also make it possible to posit phonological representations that are nearer to the systematic phonetic ones than representations which do not contain replacing endings. Witness hafs again: if the morphological representation is 
/hav $+\mathrm{s} /$, the phonological representation is likewise /hav+s/; if the morphological representation is $/ \mathrm{ha}(\mathrm{v}+\mathrm{fs} /$, the phonological representation is $/ \mathrm{hafs} /$. More examples of this kind will be found in the list below.

Sometimes the ending becomes replacing in spite of the fact that the morphological representation consisting of the stem + that ending leads to a systematic phonetic representation compatible with the surface phonetic constraints. The paradigm in which this happens is irregular. Example: acc. sg. m. annan (of annar "other, second") from /anna( $\underline{\underline{n}}+\mathrm{n} /$, versuc acc. sg. m. nokkurn (of nokkur "some") from /nokkur+n/.

English examples of replacing endings are, $/+\mathrm{vz} /$ in the plural knives $(/ \mathrm{naI}(\mathrm{f}+$ $+\mathrm{vz} /), /+\mathrm{zIz} /$ in the plural houses (/haU(s+zIz/), / / $\mathrm{dz} /$ in the plural mouths $(/ \mathrm{maU}(\theta+\mathrm{dz} /)$, and possibly $/+\hat{\mathrm{ts}} /(/ \mathrm{ts} /$ denotes an affricate $)$ in the plural cats $(/ \mathrm{kx}(\mathrm{t}+\mathrm{ts \hat {s }} /)$.

\section{Declension of Modern Icelandic Nouns}

(1) hattur $m$. "hat". Stem hatt-. Endings $/+\mathrm{Yr},+s,+\mathrm{I},--;+\operatorname{ar},+\mathrm{a},+\mathrm{Ym}$, $+a / .^{2}$ The $u$-Umlaut Rule $(/ a / \rightarrow / 0 /)$ applies in the dative plural. ${ }^{3}$

(2) skógur m. "forest". Stem /skou/. Alternatively it could be /skoux/, with / $\mathrm{x} /$ generalised from the gen. sg. skógs, which exists beside skógar, and which is pronounced with [-xs]. Two circumstances speak against the representation /skoux/: (1) $/ x /$ has been generalised from a highly marked case, and this procedure may go counter to some universal constraint on the form of underlying representations. (2) The representation /skoux/ could only be valid for those speakers using the gen. skógs. (Others use skógar.) For these reasons I set up the stem as /skou/. A consequence of this is that the definite form of the alternative dat. sg. skóg must be posited as $/$ skou $+\operatorname{gnYm} /$, and the definite form of the acc. sg. skóg as $/$ skou $+\mathrm{j} I n /$. Cf. Orešnik MSc. Endings $/+\mathrm{Yr},+\operatorname{ar}$ and $+\mathrm{xs}$, $+\mathrm{jI}$ and --, --; +ar, $+\mathrm{a},+\mathrm{Ym},+\mathrm{a} /$.

(3) bjófur $\mathrm{m}$. "thief". Stem bjóf-. Endings $/+\mathrm{Yr},+\mathrm{s}$ or $+\mathrm{f} s,+\mathrm{I}$ and,---- ; $+a r,+a,+Y m,+a /$. In the gen. /pjouv+s/ the Continuant Devoicing Rule (Orešnik 1972b) applies, changing the stem final $/ v /$ to $/ f /$. The alternative ending of the genitive singular, $/+\mathrm{fs} /$, is replacing: $/ \mathrm{pjou}(\mathrm{v}+\mathrm{fs} /$.

The definite dative singular is pjofnum [pjoubnYm], with the change of $/ \mathrm{v} /$ to $/ \mathrm{b} /$ before $/ \mathrm{n} /$, or with the replacing ending $/+\operatorname{bnYm} /: /$ pjou $(v+$ bnYm $/ \rightarrow /$ pjoubn Ym $/$. If the ending is just $/+\mathrm{nYm} /$, the change of $/ v /$ to $/ \mathrm{b} /$ is performed by a phonological rule which can be formulated as follows:

$$
\left[\begin{array}{l}
v \\
q
\end{array}\right] \rightarrow\left[\begin{array}{l}
b \\
g
\end{array}\right] / v_{-}-\left\{\begin{array}{l}
1 \\
n
\end{array}\right\}\left\{\begin{array}{l}
\# \\
v
\end{array}\right\}
$$


I. e. any $/ v /$ becomes $/ \mathrm{b} /$, and any $/ q /$ becomes $/ g /$, if preceded by a vowel and followed by $/ 1 /$ or $/ \mathrm{n} /$, which in turn are followed by a word boundary or by a vowel. - Examples: gefinn - gefnir, fífill - fíflar, saga - sagna, ígull íglar, efldi [evldI] - imp. efl, inf. efla, $\underline{\text { sigldi }}[$ sIqldI $]$ - imp. sigl, inf. sigla.

(4) akur m. "acre". Stem akur-. Endings /--, +s or +rgs, +1, --; +ar, +a, $+\mathrm{Ym},+\mathrm{a} /$. In the genitive singular the underlying representation is either /alsur+ $+s /$, in which case the Continuant Devoicing rule (Orešnik 1972b) must change $/ \mathrm{r} /$ to $/ \mathrm{r} /$, or $/$ aku( $+\underline{r} \mathbf{s} /$, with a replacing ending.

In the dative singular and throughout the plural, the Vowel Syncope Rule applies. For this rule see Orešnik MSc. The doomed vowel must fulfil three conditions: (1) It must be marked as "elidible". (2) It must be followed by at most one short consonant, the morpheme boundary, and another vowel, in that order. (3) The grammatical form in which the doomed vowel occurs must be enumerated in a list of contracted forms. These three conditions are met by the dative singular and the plural case forms of akur, but not by the definite nom. /acc. sg. akurinn, underlyingly /akur $+\mathrm{In} /$ : the nominative and accusative singular of nouns are not enumerated in the list of contracted forms.

In the dative plural the $u$-Umlaut Rule $(/ a / \rightarrow / 0 /)$ applies.

(5) söngur m. "song". Stem söng-. Endings /+Yr, +s, --, --; +var, +va, $+\mathrm{vYm},+\mathrm{va} /$. The genitive singular is phonetically [söiss], without [g], which is pronounced in the remaining case forms, except in the definite dat. sg. söngnum. The phonetical representation of the genitive singular can be produced with the help of a phonological rule which deletes $/ \mathrm{g} / \mathrm{between} / \mathrm{m} /$ and $\underline{n}, \mathrm{~d}, \underline{\mathrm{t}}, \underline{1}, \underline{\mathbf{s}} / \mathrm{but}$ not $r$ /, see Orešnik MSb. The rule cannot be formalised at present, because the deletion of $/ \stackrel{g}{\mathrm{~g}} /$ does not take place equally regularly in all of the said positions.

Theoretically the stem /söig/ could be posited, and the endings would then be g-initial, e.g. $/+\mathrm{g} Y r /$ in the nominative singular. The stem $/$ soi $i /$ would be generalised from the genitive singular and from the definite dative singular, both highly marked cases, and this procedure would presumably go counter to some universal constraint on the form of the underlying representations of stems.

In my earlier work (Orešnik 1972a) I posited a $\mathrm{v}$-final stem, /söngv/, with $/ \mathrm{v} /$ generalised from the plural case forms. For the reasons for the abolishment of this alternative see Orešnik MSc.

(6) is m. "ice". Stem ís-. Endings / $/-,+\mathrm{s}:,+\mathrm{I},--/$. The desinence $/+\mathrm{s}: /$ of the genitive singular is replacing: $/ \mathrm{i}(\mathrm{s}+\mathrm{s}: / \rightarrow /$ is: $/$. The ending is provisional, pending the formulation of the quantity rules.

(7) koss m. "kiss". Stem koss-. Endings /--, --, +I, --; +ar, +a, +Ym, $+a /$.

$\underset{+a / 4}{(8)}$ stóll "chair". Stem stöl-. Endings /infix d, +s, +I, --; +ar, +a, +Ym, 
(9) dagur $m$. "day". Stem dag-. Endings $/+\mathrm{Yr},+\mathrm{s}$ or $+\mathrm{xs},--,--;+\mathrm{ar},+\mathrm{a}$, $+\mathrm{Ym},+\mathrm{a} /$. The dative singular is also degi. The Continuant Devoicing Rule (Orešnik 1972b) applies in /daq $+s / . /+x s /$ is a replacing ending, $/ d a(q+x s /$. The $u-U m l a u t$ Rule $(/ a / \rightarrow / \ddot{o} /)$ applies in the dative plural. The Palatalisation Rule (Orešnik MSb) applies in the definite acc. sg. daginn and changes $/ q /$ to $/ j /$, whereupon the stem vowel $/ a /$ is diphthongised to an $\mathbf{i}$-diphthong.

(10) ketill m. "kettle". Two suppletive stems: katl- before vowel initial endings, ketil- elsewhere. Endings as sub (8).

(11) jökull m. "glacier". Stem jökul-. Endings as sub (8). The Vowel Syncope Rule operates in the case forms in which the desinences begin with a vowel. E.g. nom. pl. /jökul + ar $/ \rightarrow$ jöklar. Cf. (4) above. Another rule inserts an $/ \mathrm{h} / \mathrm{before} \mathrm{kl}$. For those speakers of Icelandic who pronounce aspirated plosives intervocalically. (hardmeli) the rule can be formulated as follows:

\section{H-Insertion Rule}

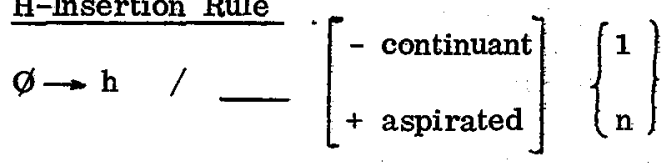

I, e. an $/ \mathrm{h} /$ is inserted before an aspirated plosive followed by $/ 1 /$ or $/ \mathrm{n} /$. Additional examples: opnir, deplar, getnir, auknir. The aspirated plosives are pronounced in the non-contracted stems opin-, depil-, getin-, aukin-. A later rule deaspirates the plosives in the environment $/ \mathrm{h} /:\left(1 \mathrm{~s} \mathrm{ph}_{\mathrm{n}} \mathrm{hr} / \rightarrow\right) / \mathrm{s} \mathrm{hp}_{\mathrm{nIr}} /$ $\rightarrow / 5 \mathrm{hpnIr} /$. - The H-Insertion Rule operates after the Vowel syncope Rule, which feeds it.

I have not yet succeeded in formulating the H-Insertion Rule for those speakers of Icelandic who pronounce non-aspirated plosives intervocalically (linmali). The main problem here is how to distinguish between words such as eitnir, which do undergo $\mathrm{H}$-Insertion, and words such as einn [eidn], which do not undergo $\mathrm{H}$-Insertion. (In hardmoli the distinction is easy to make: the plosive of etnir is underlyingly aspirated [cf. étinn with aspirated plosive], whereas that of einn is not.) I leave the problem open.

(12) ferill $\mathrm{m}$. "track, trace". Stem feril-. Endings as sub (8). The Vowel Syncope Rule operates in the case forms in which the desinences begin with a vowel. E.g. nom. pl. /feril $+a r /$ ferlar. Another rule inserts /do between $\underline{r}$ and $\underline{1}$ in the contracted cases. The rule can be formulated as follows:

D-Insertion Rule

$$
\emptyset \rightarrow \mathrm{d}_{0} / \mathrm{r}_{-}\left\{\begin{array}{l}
1 \\
\mathrm{n}
\end{array}\right\}
$$

I. e. a $/ \mathrm{d} /$ is inserted between $/ \mathrm{r} /$ and $/ 1 /$ or $/ \mathrm{n} /$. Additional example: farnir. The rule operates, e.g. in morgunn "morning", contracted stem morgn-, where 
$\underline{g}$ is first deleted between $\underline{r}$ and $\underline{n}$, and then $/ d /$ is inserted instead. Sometimes the $\underline{r}$ is deleted subsequent to the insertion of $/ d /$, i.e. the effect is as if the /d/ had not been inserted between $\underline{\mathbf{r}}$ and $\underline{1}$ or $\underline{\mathrm{n}}$, but as if the /d/ had replaced the $/ \mathbf{r} /$. For instance, the contracted stem morgn- is pronounced either as [mordin-] or as [madn-].

(13) skór m. "shoe". Stem skó-. Endings $/+r,+s,--,--;+r,+a,+m,--/$.

(14) laeknir m. "physician". (I) Stem laekn-. Endings / +Ir, +Is, +I, +I; +ar, $+a,+\mathrm{Ym},+a /$. (II) Stem laeknir-. Endings $/--,+\mathrm{s}$ or $+\mathrm{rs},--,--;+a r,+a$, $+\mathrm{Ym},+\mathrm{a} /$. The alternative genitive singular desinence $/+\mathrm{r} \mathrm{s} /$ is replacing: /aekni $(\underline{r}+\underline{r} s /$.

(15) eyrir m. "0.01 króna". Two suppletive stems: aur- in the plural, eyrelsewhere. Endings as sub (14I).

(16) sjór, saer, sjár m. "sea". (I) Stem sjó-. Endings $/+r$, +ar and $+s,--$, $--;$ +ar and $+\mathrm{Ir},+a,+\mathrm{Ym},+a$ and $+\mathrm{I} /$. (II) Stem sae-. Endings $/+r$, +var, -and $+v I,--/$. (III) Stem sjá-. Endings as sub '(II).

(17) snjór, snaer, snjár m. "snow". (I) Stem snjó-. Endings $/+r$, +ar and $+v a r,--,--;+a r,+a,+Y m,+a /$. (II) Stem snae--. Endings as sub (16 II). (III) Stem snjá-. Endings as sub (16 II).

(18) smíeur m. "smith". Stem smía-. Endings /+Yr, +s, --, --; +Ir, +a, $+\mathrm{Ym},+\mathrm{I} /$.

(19) leikur m. "play". Stem leik-. Endings /+Yr, $+\mathrm{s},--,--;+\mathrm{Ir},+\mathrm{k}_{\mathrm{j}} \mathrm{a},+\mathrm{k}_{\mathrm{j}} \mathrm{Ym}$, $+\mathrm{I} /$. The desinences of the genitive and dative plural are replacing: / lei $\left(\mathrm{k}+\mathrm{k}_{\mathrm{ja}} \mathrm{a}\right.$ and $/$ lei $\left(k+k_{j} \mathrm{Ym} /\right.$. In the definite dat. sg. leiknum the H-Insertion Rule, formulated sub (11) above, applies. Before $/ \mathrm{I} /$-initial desinences the stem final $\underline{\mathrm{k}}$ is palatalised by the Palatalisation Rule (Orešnik MSb).

(20) veggur $m$. "wall". Stem vegg-. Endings $/+\mathrm{Yr},+\dot{g}_{\mathrm{j}} \mathrm{ar}$ and $+\mathrm{s},--,--;+\mathrm{Ir}$,

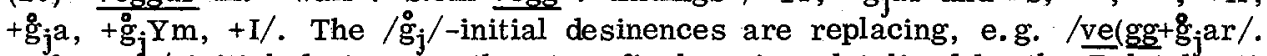
Before ///-initial desinences the stem final $\mathrm{gg}$ is palatalised by the Palatalisation Rule (Orešnik MSb). - The problems connected with (19) and (20) are treated in Orešnik MSd.

(21) baer m. "farm, town". Stem bae-. Endings / $+\mathrm{r},+$ jar, --, --; +jIr, +ja, $+\mathrm{jYm}, \overline{+\mathrm{jI} /}$.

(22) hlutur m. "thing". Stem hlut-. Endings /+Yr, +ar, --, --; +Ir, +a, +Ym, $+\mathrm{I} /$. In the definite dat. sg. hlutnum the H-Insertion Rule, formulated sub (11) above, applies.

(23) fatnadur m. "clothing". (a) Stem fatnad-. Endings /+Yr, +ar, +I, --; +Ir, $+\mathrm{a},+\overline{\mathrm{Ym}},+\mathrm{I} /$. The $\mathrm{u}-$ Umlaut Rule $(/ \mathrm{a} / \overrightarrow{\mathrm{O}} /$ and $/ \mathrm{a} / \rightarrow / \mathrm{Y} /)$ applies in the 


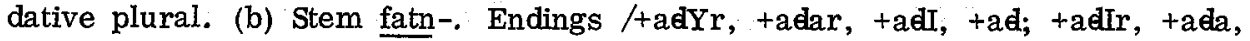
$+\mathrm{YAYm},+\mathrm{adI} /$. The $\mathrm{u}$-Umlaut Rule $(/ \mathrm{a} / \rightarrow / \mathrm{o} /)$ applies in the dative plural. (c) Stem fat-. Endings / nadYr, +nadar, +nadI, +nad; +nadIr, +nada, +nYdYm, +nadI/. The u-Umlaut Rule $(/ a /-/ o /)$ applies in the dative plural. - See Orešnik MSa.

(24) söfnudur $m$. "congregation". (a) Stem söfnud-. Endings as sub (23a). In the genitive of both numbers the u-Umlaut Rule changes $/ 0 /$ and $/ Y /$ to $/ a /:$ safnadar, safnada. (b) Stem söfn-. Endings /+YdYr, +adar, +YdI, +Yd; +YdIr, +ada, +YdYm, $+\mathrm{YdI} /$. In the genitive of both numbers the u-Umlaut Rule changes $/ \mathrm{o} /$ to $/ a /$. (c) Stem safnad-. Endings as sub (23a). Outside the genitives of both numbers the $\mathrm{u}$-Umlaut Rule changes the /a/ under primary stress to $/ 0 /$, and the stressless /a/ to $/ Y /$. (d) Stem safn-. Endings as sub (b). Outside the genitives of both numbers the $u$-Umlaut Rule changes the $/ a /$ of the stem to $/ 0 /$. - See Oresnik MSa.

(25) köttur m. "cat". Three suppletive stems: katt- in the genitives, kett- in the dative singular, nominative and accusative plural, kött- elsewhere. Endings as sub (23a).

(26) fjörtur $\mathrm{m}$. "fjord". Three suppletive stems: fjard- in the genitives, firdin the dative singular, nominative and accusative plural, fjörd- elsewhere. Endings as sub (23a).

(27) spónn $\mathrm{m}$. "spoon". Two suppletive stems: spaen- in the dative singular, nominative and accusative plural, spón- elsewhere. Endings /infix d, +s, +I, --; $+\mathrm{Ir},+\mathrm{a},+\mathrm{Ym},+\mathrm{I} /$.

(28) sonur m. "son". Two suppletive stems: syn- in the dative singular, nominative and accusative plural, son- elsewhere. Endings as sub (23a).

(29) fadir $\mathrm{m}$. "father". Three suppletive stems: fedur- in the plural, $\underline{\mathrm{u}}$ is "elidible"; fötur- in the singular outside the nominative; fadir-elsewhere. Endings $/--,--$ and definite $+\operatorname{sins}$ or $+r \operatorname{sins},--,--;--,+a,+Y m,--/$. The alternative ending of the definite genitive singular, $/+\underline{r}$ sIns/, is replacing: /fölu $(\underline{\mathbf{r}}+$ $+r \sin s /$.

(30) bródir $\mathrm{m}$. "brother". Three suppletive stems: braedur- in the plural, $\underline{\mathrm{u}}$ is "elidible"; bródur- in the singular outside the nominative; brodir- elsewhere. Endings as sub (29).

(31) fótur m. "foot". Two suppletive stems: faet- in the dative singular, nominative and accusative plural, fót- elsewhere. Endings $/+\mathrm{Yr},+\mathrm{ar},+\mathrm{I},--;+\mathrm{Yr}$, $+\mathrm{a},+\mathrm{Ym},+\mathrm{Yr} /$.

(32) fingur $m$. "finger". Stem fingur-; u is "elidible". Endings $/--$, $+s$ or $+\mathrm{rs},+\mathrm{I},--;--,+\mathrm{a},+\mathrm{Ym},--/$. The alternative desinence of the genitive singular, / $+\mathrm{rs} /$, is replacing: /fingu $(\underline{r}+\underline{r} s /$. 
(33) vetur m. "winter". Stem vetur-; $\underline{\text { u }}$ is "elidible". Endings as sub (32).

(34) madur m. "man". Three suppletive stems: menn- in the nominative/accusative plural, madur- in the nominative singular, mann- elsewhere. Endings /--, $+\mathrm{s},+\mathrm{I},--; \overline{--}$ and definite $+\mathrm{I}(\mathrm{d}) \mathrm{nIr},+\mathrm{a},+\mathrm{Ym},--/$. The $\mathrm{u}-\mathrm{Umlau}$ Rule $(/ \mathrm{a} /-/ \mathrm{o} /)$ applies in the dative plural.

(35) tími m. "time". Stem tím-. Endings $/+\mathrm{I},+a,+a,+a ;+a r,+a,+Y m,+a /$.

(36) afi m. "grandfather". Stem af-. Endings as sub (35). The u-Umlaut Rule $(/ a /-/ 0 /)$ applies in the dative plural.

(37) bakari m. "baker". (a) Stem bakar-, Endings as sub. (35). The u-Umlaut Rule $(/ \mathrm{a} /-/ \mathrm{o} /$ and $/ \mathrm{a} /-/ \mathrm{Y} / \mathrm{h}$ applies in the dative plural. (b) Stem bak-. Endings /+arI, +ara, +ara, +ara; +arar, +ara, +YrYm, +ara/. The u-Umlaut Rule $(/ \mathrm{a} / \rightarrow / \mathrm{o} /)$ applies in the dative plural.

(38) kunningi m. "acquaintance". Stem kunning ${ }_{j}-$. Endings as sub (35).

(39) Dani m. "Dane". Stem Dan-. Endings / $+\mathrm{I},+a,+a,+a ;+I r,+a,+Y m,+I /$. The $u$-Umlaut Rule $(/ a /-/ 0 /)$ applies in the dative plural.

(40) herra m. "sir, Mr.". Stem herr-. Endings $/+a,+a,+a,+a$; +ar, +a, $+Y m,+a /$.

(41) séra $\mathrm{m}$. "Reverend". Only the singular is used. Indeclinable.

(42) fraendi m. "relative". Stem fraend-. Endings $/+I,+a,+a,+a ;+Y r,+a$,

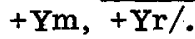

(43) nemandi $\mathrm{m}$. "pupil". Two suppletive stems: nemend- in the plural, nemandelsewhere. Endings as sub (42).

(44). bóndi m. "farmer". Two suppletive stems: baend- in the plural, bondelsewhere. Endings as sub (42).

(45) fjandi $\mathrm{m}$. (I) "enemy". Two suppletive stems: fjend- in the plural, fjandelsewhere. Endings as sub (42). (II) "devil". Stem fjand-. Endings as sub (35). The $u$-Umlaut Rule $(/ a /-/ 0 /)$ applies in the dative plural.

(46) kinn f. "cheek". Stem kinn-. Endings /--, +ar, --, --; +ar, +a, +Ym, $+\operatorname{ar} /$.

(47) kerling f. "old woman". Stem kerling-. Endings /--, +ar, +Y, +Y; +ar, $+a,+Y m,+a r /$.

(48) lifur f. "liver". Stem lifur-; $\underline{u}$ is "elidible", cf. lifr-in, lifr-ar, etc. Endings as sub (46). 
(49) Hildur f. woman's name. Stem Hild-. Endings $/+Y r,+a r,+I,+I$; +ar, $+\mathrm{a},+\mathrm{Ym},+\mathrm{ar} /$.

(50) heidi f. "heath". Stem heid-. Endings / I, +ar, +I, +I; +ar, +a, +Ym, +ar/.

(51) âa f. "river". Stem á--. Endings $/--,+r,--,--;+r,+a,+m,+r /$.

(52) stöd f. "station". Stem stöd-. Endings /--, +var, --, --; +var, +va, $+\mathrm{vYm},+\mathrm{var} /$.

(53) skel f. "shell". Stem skel-. Endings /--, +jar, --, --; +jar, +ja, +jYm, + jar/.

(54) djörfung f. "courage". Endings /--, +ar, +Y, --/.

(55) brúdur f. "bride". Stem brúd-. Endings $/+\mathrm{Yr},+\mathrm{ar},+\mathrm{I},+\mathrm{I} ;+\mathrm{Ir},+\mathrm{a},+\mathrm{Ym}$, $+\operatorname{Ir} /$.

(56) Pórdís f. woman's name. Stem Pórdís-. Endings /--, +ar, +I, +I/.

(57) frú f. "lady". Stem frú-. Endings /--, +ar, --, --; +r, +a, +m, +r/. Indeclinable before a personal name.

(58) Gudný f. woman's name. Stem Guenjy-- Endings $/--,+j a r,+j \mathrm{Y},+\mathrm{jY} /$.

(59) tíd f. "time". Stem tía - Endings /--, +ar, --, --; +Ir, +a, +Ym, +Ir/.

(60) gjöf f. "present". As suggested in Orešnik MSa, the gjöf nouns display two stems: /g $/{ }_{j}$ ov $/$ in the singular, with the $u-U m l a u t$ Rule $(/ \ddot{o} / \longrightarrow / a /)$ applying in the genitive singular; $/ g_{j}$ av/ in the plural, with the $u$-Umlaut Rule $(/ a / \rightarrow / 0 /)$ applying in the dative plural. The relationship between the two stems is either suppletive, or one is derived from the other (the plural stem from the singular stem) with the help of a rule. Endings as sub (59).

(61) verzlun f. "trade". (a) As sub (60), there are two stems, verzlun-, used in the singular, and verzlan-, used in the plural. The u-Umlaut Rule $(/ a /-/ Y /)$ applies in the dative plural. The relationship between the two stems is either suppletive or they are related by rule. Endings as sub (59). (b) Stem verzl-. Endings /+Yn, + Ynar, +Yn, +Yn; +anIr, +ana, +YnYm, +anIr/.

(62) pöntun f. "commercial order". (a) Two stems, pöntun- in the singular, and pantan- in the plural. The u-Umlaut Rule $(/ a / \rightarrow / 0 /$ and $/ a /-/ Y /)$ changes pantan- to pöntun- in the dative plural. Endings as sub (59). (b) Two stems, pönt- in the singular and pant- in the plural. The u-Umlaut Rule $(/ a / \rightarrow / 0 /)$ changes pant- to pönt- in the dative plural. The relationship between the singular and the plural stems is either suppletive or rule governed. Endings as sub (61b). 
(63) alin f. "ell". Two suppietive stems: áln- in the genitive singuiar and in the plural, alin- elsewhere. Endings as sub (59).

(64) skipan f. "order, arrangement". (a) Stem skipan-. Endings as sub (59). The $u$-Umlaut Rule $(/ \mathrm{a} / \rightarrow / \mathrm{Y} /)$ changes skipan- to skipun- in the dative plural. (b) Stem skip-. Endings / +an, tanar, +an, tan; +anIr, +ana, +YnYm, +anIr/.

(65) sól f. "sun". Stem sól-. Endings /--, +ar, +Y, +Y; +Ir, +na, +Ym, +Ir/.

(66) steik f. "roast". Stem steik-. Endings /--, +ar, --, --; +Yr, +a, +Ym, $+\mathrm{Yr} /$. The genitive singular is also steikur.

(67) mörk f. "pint, half a pound, forest". Three suppletive stems:

mark- in the genitive and dative plural. The $u$-Umlaut Rule $(/ a / \rightarrow / 0 /)$ changes mark- to mörk- in the dative plural. Cf. giöf.

merk- in the nominative/accusative plural.

mörk- elsewhere. The $u$-Umlaut Rule $(/ 0 / \rightarrow / a /)$ changes mörk- to markin the genitive singular. Cf. gjöf.

The genitive singular is also merkur. Endings as sub (66).

(68) bók f. "book". Two suppletive stems: baek- in the nominative/accusative plural, bók- elsewhere. Endings as sub (66).

(69) brú f. "bridge". Two suppletive stems: brý- in the nominative/accusative plural, brú- elsewhere. Endings /--, +ar, --, --; +r, +a, +m, +r/.

(70) kýr f. "cow". Two suppletive stems: ký- before $/+r /$, kú- elsewhere. Endings $/+r,+r,--,--;+r,+a,+m,+r /$.

(71) módir f. "mother". Three suppletive stems: maedur- in the plural; $\underline{u}$ is "elidible"; módur- in the singular outside the nominative; módir- elsewhere.

Endings /--, --, --, --; --, +a, +Ym, --/.

(72) dóttir f. "daughter". Three suppletive stems: daetur- in the plural, u is "elidible"; dottur- in the singular outside the nominative; dottir- elsewhere. Endings as sub (71).

(73) systir f. "sister". Two suppletive stems: systur- outside the nominative singular, systir- elsewhere, Endings as sub (71). $\underline{u}$ of systur- is "elidible".

(74) mús f. "mouse". Two suppletive stems: mýs- in the nominative/accusative plural, mús- elsewhere. Endings $/--,+$ ar, --, --; --, +a, +Ym, --/.

(75) hönd f. "hand". Three suppletive stems:

hend- in the dative singular and nominative/accusative plural. 
hand- in the genitive and dative plural. The u-Umlaut Rule $(/ a / \rightarrow / 0 /)$ changes hand- to hönd- in the dative plural. Cf. gjöf.

hönd- elsewhere. The u-Umlaut Rule $(/ \ddot{\partial} / \rightarrow / a /)$ changes hönd- to handin the genitive singular. Cf. gjöf.

Endings /--, +ar, +I, --; +Yr, +a, +Ym, +Yr/.

(76) nottt f. "night". Two suppletive stems: naet- in the genitive singular and nominative/accusative plural, nótt- elsewhere. Endings /--, +Yr, -- and $+Y$, $--;+\mathrm{Yr},+\mathrm{a},+\mathrm{Ym},+\mathrm{Yr} /$.

(77) tunga f. "tongue". Stem tung-. Endings $/+a,+Y,+Y,+Y ;+Y r,+n a,+Y m$, $+\mathrm{Yr} /$. In the genitive plural $/ \mathrm{g} / \mathrm{is}$ deleted between $/ \mathrm{m} /$ and $/ \mathrm{n} /$ by a rule discussed in Orešnik MSb fn. 2. Cf. also (5) above.

(78) saga f. "story". The stem is /söq/, see Orešnik MSa. The u-Umlaut Rule $(/ \ddot{o} /-/ a /)$ changes /söq/ to /saq/ in the nominative singular and the genitive plural. Endings as sub (77), except that the genitive plural desinence may be $/+$ gna/ instead of $/+\mathrm{na} / ; /+\mathrm{gna} /$ is a replacing ending: $/ \mathrm{sa}(\mathrm{q}+\mathrm{g}$ ma/. If the ending is $/+n a /$, a phonological rule changes $/ q /$ to $/ g /$ before $/ n /$. The rule is formulated above sub (3).

(79) amma f. "grandmother". The stem is ömm-, cf. Orešnik MSa. The u-Umlaut Rule $(/ 0 / \rightarrow / a /)$ changes it to amm- in the nominative singular and the genitive plural. Endings $/+a,+Y,+Y, \overline{+Y} ;+Y r,+a,+Y m,+Y r /$.

(80) gáfa f. "talent". Stem gáf-. Endings as sub (77), except that the genitive plural desinence may be the replacing / $/$ bna/: /gá $(f+b n a \%$ The same ending is added in rofa, see (81). If the genitive plural desinence is $/+n a /$, a phonological rule changes the stem final $/ v /$ to $/ b /$, see (3) above.

(81) rófa f. "tail". Stem /rou/. Endings $/+a,+Y,+Y,+Y ;+Y r$, +bona, +Ym, $+\mathrm{Yr} /$.

(82) mínúta f. "minute". Stem mínút-. Endings as sub (77). A phonological rule, formulated above sub (11), inserts $/ \mathrm{h} /$ before $\mathrm{t}$ in the gen. pl. /minut + na/.

(83) stúlka f. "girl". Stem stúlk-. Endings as sub (77). The genitive plural is alternatively pronounced as if spelled stültna. This form is either suppletive (i.e. has to be remembered) or contains the replacing ending $/+\operatorname{lgdna}^{2} /: /$ stú $_{\text {lk }}+$ +lodna/.

(84) ekkja f. "widow". Stem ekkj-. Endings as sub (77), except that the genitive plural desinence is replacing, $/+\mathrm{gna} /: / \mathrm{eh}\left(\mathrm{k}_{\mathrm{j}}+\mathrm{g} n \mathrm{n} /\right.$. If the genitive plural desinence were just $/+n a /$, there would arise the problem of the depalatalisation of the stem final segment before $/+n a /$. A depalatalisation rule is otherwise not necessary in Modern Icelandic phonology. Cf. Orešnik MSb. 
(85) kona f. "woman, wife". Two suppletive stems: kvenn- in the genitive plural, kon- elsewhere. Endings as sub (79).

(86) lygi f. "lie". Stem /liq/. Endings $/+\mathrm{I},+\mathrm{I},+\mathrm{I},+\mathrm{I}$; +ar, $+\mathrm{a},+\mathrm{Ym},+\mathrm{ar} /$. The segment $/ q /$ of the stem is palatalised to $/ \mathrm{j} /$ before $/+\mathrm{I} /$ by the Palatalisation Rule (Orešnik MSb). The stem vowel /I/ is forwarded/raised to /i/ before $/ \mathrm{j} /$. The rule performing this has not yet been formulated. It diphthongises the vowels /a, e, o, $\mathrm{Y}, \ddot{b} /$ into the corresponding i-diphthongs, and forwards/raises $/ \mathrm{I} /$ to $/ \mathrm{i} /$. A unified account of these two processes presents unsurmountable difficulties for the time being.

(87) fraedi f. "learning". Used in the singular only. Indeclinable.

(88) aevi f. "life". Stem aev-. Endings $/+\mathrm{I},+\mathrm{I},+\mathrm{I},+\mathrm{I} ;+\mathrm{Ir},+\mathrm{a},+\mathrm{Ym},+\mathrm{Ir} /$

(89) bord n. "table". Stem bord-. Endings /--, +s, +I, --; --, +a, +Ym, --/.

(90) barn n. "child". Stem barn-. Endings as sub (89), except in the genitive singular. I do not yet know which rules, if any, account for the gen. sg. [bas:] The $u$-Umlaut Rule $(/ a /-/ o /)$ applies in the nominative/accusative and dative plural.

(91) haf n. "sea". Stem haf-. Endings /--, +s or +fs, +I, --; --, +a, +Ym, $--/$. If the desinence of the genitive singular is $/+\mathrm{s} /$, the underlying representation of the genitive singular is /hav $\mathrm{s} /$, and a devoicing rule must change $/ \mathrm{v} /$ to /f/ before /s/. Such a rule has been formulated in Orešnik 1972b. On the other hand, the ending may be $/+\mathrm{fs} /$ and replacing: $/ \mathrm{ha}(\mathrm{v}+\mathrm{fs} /$. In the nominative/ accusative and dative plural the u-Umlaut rule applies, changing haf- to höf--

(92) kym n. "kin". Stem kyn-. Endings $/--,+s,+1,--;--,+j a,+j Y m,--/$

(93) tré n. "tree". Two suppletive stems: trjá- in the genitive and dative plural, tré- elsewhere. Endings $/--,+s,--,--;--,+a,+m,--/$.

(94) hreidur n. "nest". Stem hreidur-; u is "elidible". Endings /--, +s or + rss, $+\mathrm{I},--;--,+\mathrm{a},+\mathrm{Ym},--/$. The genitive singular ending $/+\mathrm{s} / \mathrm{causes}$ devoicing of the stem final $\underline{r}$, cf. Orešnik 1972b. The alternative genitive singular ending $/+\mathrm{rs} /$ is replacing: / $\underline{\mathrm{hrei} u}(\underline{\mathrm{r}}+\mathrm{rs} /$.

(95) medal n. "medicine". Stem medal-. Endings as sub (89). The u-Umlaut Rule $(/ \mathrm{a} / \rightarrow / \mathrm{o} /)$ and, alternatively, $/ \mathrm{a} / \rightarrow / \mathrm{Y} / \mathrm{)}$ applies in the nominative/accusative and dative plural.

(96) sumar n. "summer". Stem sumar-. The unstressed vowel is "elidible", nevertheless the Vowel Syncope Rule does not apply in the definite nominative/ accusative singular (which is sumarid, not sumrid) and optionally in the definite nominative/accusative plural (which is sumurin beside the expected sumrin). The $\mathrm{u}$-Umlaut Rule $(/ \mathrm{a} /-\mathrm{Y} / \mathrm{)}$ applies in sumurin, vacuously presumably also in the dative plural. Endings as sub (89). The noun is irregular, cf. Orešnik MSa. 
(97) kvaedi n. "poem". Stem kvaed-. Endings $/+\mathrm{I},+\mathrm{Is},+\mathrm{I},+\mathrm{I} ;+\mathrm{I},+\mathrm{a},+\mathrm{Ym}$, $+\mathrm{I} /$.

(98) ríki n. "state". Stem $\underline{\text { rík }}_{\mathrm{j}}$-. Endings as sub (97).

(99) vígi n. "fortress". Stem /vij/. Endings as sub (97).

(100) böl n. "calamity". Stem böl-. Endings /--, +s, +vI and +I, --; --, +va, $+\mathrm{vYm},--1$.

(101) fé n. "sheep". Two suppletive stems: fjá- in the genitive singular, genitive and dative plural, fé- elsewhere. Endings $/--,+r,--,--;--,+a,+m,--/$

(102) lát n. "death". Stem lát-. Endings as sub (89).

(103) laeti n. pl. "noise". Two suppletive stems: lát- in the genitive and dative plural, laet- elsewhere. Endings $/+\mathrm{I},+a,+\mathrm{Ym},+\overline{\mathrm{I} /}$.

(104) altari n. "altar". (a) Stem altar-. Endings $/+\mathrm{I},+\mathrm{Is},+\mathrm{I},+\mathrm{I} ;+\mathrm{Y},+\mathrm{a},+\mathrm{Ym}$, $+\mathrm{Y} /$. The $\mathrm{u}$-Umlaut Rule $(/ \mathrm{a} /-\overline{\mathrm{o} /}$ and $/ \mathrm{a} / \rightarrow / \mathrm{Y} /$ ) applies in the nominative/ accusative and dative plural. (b) Two suppletive stems: öltur- in the nominative/ accusative and dative plural, altar-elsewhere. Endings as sub (a).

(105) auga n. "eye". Stem aug-. Endings $/+a,+a,+a,+a ;+Y,+n a$ or +g̊na, $+\mathrm{Ym},+\mathrm{Y} /$. In /aug+na/ the phonological rule formulated sub (3) above changes the stem final $/ \mathrm{q} /$ to $/ \stackrel{\circ}{\mathrm{g}} /$. The alternative genitive plural desinence $/+\mathrm{g} n \mathrm{~h} /$ is replacing: / $\underline{\mathrm{au}}(\mathrm{g}+\mathrm{g} \mathrm{g}$ a/.

(106) hjarta n. "heart". Stem hjart-. Endings $/+a,+a,+a,+a ;+Y$, +na, +Ym, $+\mathrm{Y} /$. The $\mathrm{u}-$ Umlaut Rule $(/ \mathrm{a} / \overline{\mathrm{o}} /)$ changes hjart- to hjört- in the nominative/ accusative and dative plural.

(107) eyra n. "ear". Stem eyr-. Endings as sub (106). A phonological rule, formulated sub (12) above, inserts / $d / d$ between $\underline{r}$ and $\underline{n}$ in the genitive plural leyr+na/.

\section{Declension of the postpositive definite article}

(108) hestur m. "horse": hestur $/+\operatorname{In} /$, hests $/+\operatorname{Ins} /$, hesti $/+n Y m /$, hest $/+\operatorname{In} /$; hestar $/+\mathrm{nIr} /$ or $/+$ dnIr $/$, hesta/+na/, hest $/+\mathrm{YnYm} /$ and $/+$ on Ym/, hesta $/+n a /$. The definite article is everywhere added to the case marker, except in the dative plural, where the article replaces the case marker. In hestar $/+n I r /$ the D-Insertion Rule, formulated sub (12) above, inserts a $/ d /$ between $/ \mathbf{r} /$ and $/ n /$.

(109) bjófur m. "thief": bjófur $/+\mathrm{In} /$, pjófs $/+\operatorname{Ins} /$, jjofof $/+\mathrm{nYm} /$ or bjóff $/+$ bnYm $/$,




bjofa $/+n a /$. For the dative singular see no. (3) above. In bjofar $/+n I r /$ the D-Insertion Rule, formulated sub (12) above, inserts a $/ d /$ between $/ \mathrm{r} /$ and $/ \mathrm{n} /$.

(110) skógur m. "forest": skógur/+In/, skógar/+Ins/ and skógs/+Ins/, skógi/ $+n Y m /$ and skóg/+g̊nYm/, skóg/+jIn/; skógar/ + nIr / or $/+\operatorname{dn} I r /$ skóga $/+n a /$, skóg/+YnYm/ and / + onYm/, skóga/+na/. The stem is /skou/, see no. (2) above. In skógar/ $/$ nIr/ the D-Insertion Rule, formulated sub (12) above, applies.

(111) skór m. "shoe": skór/+In/, skós/+Ins/, skó/+nYm/, skó/+In/; skór/ $+\mathrm{nIr} /$ or $/+d \mathrm{dnIr} /$, skó/ $+\mathrm{n}: \mathrm{a} /$, skó $/+\mathrm{nYm} /$, skó $/+\mathrm{na} /$. The article replaces the case marker in the genitive plural as well as in the dative plural. The desinence $/+n: a /$ is provisional, pending the formulation of the quantity rules. In skór $/+n I r /$ the D-Insertion Rule, formulated sub (12) above, applies.

(112) tími m. "time": tími $/ \mathrm{n} /$, tíma $/+\mathrm{ns} /$ tíma $/+\mathrm{nYm} /$ tíma $/+n /$ tímar $/+\mathrm{nIr} /$

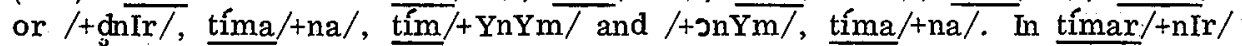
the D-Insertion Rule, formulated sub (12) above, applies.

(113) madur m. "man": madur $/+\operatorname{In} /$ manns $/+\operatorname{Ins} /$, manni $/+n Y m /, \underline{\operatorname{mann}} /+\mathrm{In} /$;



(114) kinn f. "cheek": kinn/+In/, kinnar $/+\operatorname{Inar} /$, kinn/+InI/, kinn/+Ina/; kinnar-

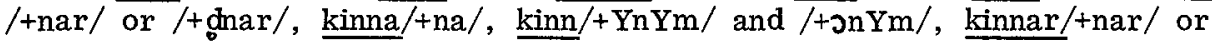
$1+$ dnar/. In kinnar/+nar/ the D-Insertion Rule, formulated sub (12) above, applies.

(115) á f. "river": a


in the genitive plural as well as in the dative plural. The endings containing $/ \mathrm{n}: /$ are provisional, pending the formulation of the quantity rules. In a r $/+$ nar/ the D-Insertion Rule, formulated sub (12) above, applies.

(116) lilja f. "lily": lilja/+n/, lilju/+nar/, lilju/+nI/, lilju/+na/; liljur/+nar/

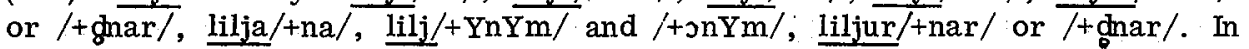
liljur/+nar/ the D-Insertion Rule, formulated sub (12) above, applies.

(117) kerling f. "old woman": kerling/ $+\mathrm{In} /$, kerlingar $/+\operatorname{Inar} /$, kerlingu/ + nI/, kerlingu/+na/; kerlingar $/+$ nar/ or $/+$ gnar $/$, kerlinga $/+$ na $/$, kerling/+YnYm/ and /+onYm/, kerlingar/+nar/ or / dnar/. In kerlingar/+nar/ the D-Insertion Rule, formulated sub (12) above, applies. Before /I/-initial endings the stem final $/ \dot{\mathrm{g}} /$ is palatalised to $/ \mathrm{g}_{\mathrm{j}} /$ by the Palatalisation Rule (Orešnik MSb), and $/ \mathrm{m} /$ is $\mathrm{pa}-$ latalised to $/ \tilde{\mathrm{n}} /$.

(118) barn n. "child": barn $/+$ Id $/$, barns $/+$ Ins $/$, barni $/+n Y m /$, barn $/+$ Id $/$;




(119) tré n. "tree": tré/+d/, trés/+Ins/, tré/+nY/, tré/+d/; tré/+n/, trjá/n:a/, trja $/+n \overline{Y m} /$, tre $/+n /$. The article replaces the case marker in the genitive plu$\mathrm{ral}$ as well as in the dative plural. The ending $/+\mathrm{n}: \mathrm{a} /$ is provisional, pending the formulation of the quantity rules.

(120) auga $n$. "eye": auga/ $/ \mathrm{d} /$, auga $/+n s /$, auga $/+n Y /$ auga $/+d /$; augu $/+n /$, augna $/+\mathrm{na} /$, aug $/+\mathrm{YnYm} /$ and $/+\mathrm{pnYm} /$, augu/ $/ \mathrm{n} /$.

\section{Declension of Modern Icelandic Adjectives}

(121) gulur "yellow". Stem gul-. Endings: strong $\mathrm{m} . / \mathrm{Yr},+\mathrm{s},+\mathrm{Ym},+\mathrm{an}$; $+\mathrm{Ir},+\mathrm{ra},+\mathrm{Ym},+\mathrm{a} /$, f. $/--$, +rar, $+\mathrm{rI},+\mathrm{a} ;+\mathrm{ar},+\mathrm{ra},+\mathrm{Ym},+\mathrm{ar} /, \mathrm{n} . /+\mathrm{t}$ or $+\mathrm{lt},+\mathrm{s},+\mathrm{Y},+\mathrm{t}$ or $+\mathrm{lt}$; $--,+\mathrm{ra},+\mathrm{Ym},--/$; weak $\mathrm{m} . /+\mathrm{I},+\mathrm{a},+\mathrm{a},+\mathrm{a} ;+\mathrm{Y},+\mathrm{Y}$, $+\mathrm{Y},+\mathrm{Y} / \mathrm{f}$. . $/ \mathrm{a},+\mathrm{Y},+\mathrm{Y},+\mathrm{Y} ;+\mathrm{Y},+\mathrm{Y},+\mathrm{Y},+\mathrm{Y} /$, n. $/+\mathrm{a},+\mathrm{a},+\mathrm{a},+\mathrm{a} ;+\mathrm{Y},+\mathrm{Y}$, $+\mathrm{Y},+\mathrm{Y} /$. Comparative m.f. / $+\operatorname{arI},+\operatorname{arI},+\operatorname{arI},+\operatorname{arI}$; $+\operatorname{arI},+\operatorname{arI},+\operatorname{arI},+\operatorname{arI} /$, n. / +ara, +ara, +ara, +ara; +arI, +arI, +arI, +arI/. superlative, strong $m$. /+astYr, +asts, +YstYm, +astan; +astIr, +astra, +YstYm, +asta/, f. /+Yst, +astrar, +astrI, +asta; +astar, +astra, +YstYm, +astar/, n. /+ast, +asts, +YstY, +ast; +Yst, +astra, +YstYm, +Yst/; weak m. /+astI, +asta, +asta, +asta; +YstY, $+Y s t Y,+Y s t Y,+Y s t Y /$, f. /+asta, +YstY, +YstY, +YstY; +YstY, +YstY, +YstY, $+Y s t Y /$, n. /+asta, +asta, +asta, +asta; +YstY, +YstY, +YstY, +YstY/. The alternative desinence / $+\mathrm{l} t /$ of the strong nominative/accusative singular neuter is replacing: /gu( $1+1+1 /$. In /gul $+t /$ the T-Devoicing Rule (Orešnik 1972b) applies.

In what follows the case forms of the weak positive, of the comparative and of the superlative will not be indicated, excepting the nominative singular masculine of the weak positive, the nominative singular masculine of the comparative, and the strong nominative singular masculine of the superlative.

(122) fagur "fair". Two suppletive stems: fegur- optional in the non-positive, fagur- used elsewhere, i.e. in the positive and optionally in the non-positive. In fagur- $\underline{u}$ is invariably, in fegur- optionally "elidible". Endings: strong $\mathrm{m}$. / --, $+\mathrm{s}$ or $+\mathrm{rs},+\mathrm{Ym},+a n ;+\mathrm{Ir},+a,+Y m,+a /, \mathrm{f} . /--,+a r,+1,+a ;+a r,+a,+Y m$, $+\mathrm{ar} /$, n. $/+\mathrm{t}$ or $+\mathrm{rt}$, $+\mathrm{s}$ or $+\mathrm{rs},+\mathrm{Y},+\mathrm{t}$ or $+\mathrm{rt} ;--,+\mathrm{a},+\mathrm{Ym},--/$; weak $/+\mathrm{I} /$. Comparative fagur/+arI/ and fegur/ $+\mathrm{I} /$. Superlative fagur/+astYr/ and fegur $/+\mathrm{stYr} /$ or $/+\mathrm{rsstYr} /$. The desinences $/+\mathrm{rs} /, 1+\mathrm{rt} /$, and $/+{ }_{\mathrm{r} s \mathrm{stY} /}$ are replacing, e.g. /fagu( $+\underline{r} \mathbf{r} s /$. The Vowel Syncope Rule applies in the following strong cases: dative singular masculine, accusative singular masculine, nominative plural masculine, dative plural, accusative plural masculine, accusative singular feminine, nominative/accusative plural feminine, dative singular neuter; in all the cases of the comparative (optionally in fegur-); in all the cases of the superlative in the stem fagur-. The $u$-Umlaut Rule $(/ \mathrm{a} / \mathrm{o} / \mathrm{d})$ applies in the following strong cases of the positive and superlative fagur-: dative singular masculine, dative plural, nominative singular feminine, dative singular neuter, nominative/accusative plural neuter; in the following weak cases: the plural, oblique feminine singular. The Continuant Devoicing Rule (Orešnik 1972b) applies in /fagur $+\mathrm{s} /$, /fagur $+\mathrm{t} /$, and /fegur + stYr/. 
(123) hár "high". Two suppletive stems: hae- in the non-positive, há-elsewhere. Endings: strong $\mathrm{m} . / \mathrm{tr}, \mathrm{s},+\mathrm{Ym},+\mathrm{an} ;+\overline{\mathrm{Ir}},+\mathrm{r}: \mathrm{a},+\mathrm{Ym},+\mathrm{a} /$, f. $/ \overline{-},+\mathrm{r}: \mathrm{ar}$, $+\mathrm{r}: \mathrm{I},+\mathrm{a} ;+\mathrm{ar},+\mathrm{r}: \mathrm{a},+\mathrm{Ym},+\mathrm{ar} / \mathrm{n}$. $/+\mathrm{ht},+\mathrm{s},+\mathrm{Y},+\mathrm{ht} ;--,+\mathrm{r}: \mathrm{a},+\mathrm{Ym},--/$; weak / $+\mathrm{I} /$; comparative / $+\mathrm{r}: \mathrm{I} /$; superlative $/+\mathrm{stYr} /$. The desinences containing $/ \mathrm{r}: /$ are provisional, pending the formulation of the quantity rules.

(124) nýr "new". Stem nȳ-. Endings: strong $m . /+r,+s,+j Y m,+j a n ;+j I r$, $+r: a,+j Y m,+j a /$, f. /--, +r:ar, +r:I, +ja; +jar, +r:a, +jYm, +jar/, n. / + ht, $+\mathrm{s},+\mathrm{jY},+\mathrm{ht} ;--,+\mathrm{r}: \mathrm{a},+\mathrm{jYm},--/$; weak $/+\mathrm{jI} /$; comparative $/+\mathrm{r}: \mathrm{I} /$; superlative $/+\mathrm{jastYr} /$. The endings containing /r:/ are provisional, pending the formulation of the quantity rules.

(125) midur "in the middle". Stem mid-. Endings: strong $\mathrm{m} . /+\mathrm{Yr},+\mathrm{s},+\mathrm{jYm}$, +jan; +jIr, +ra, +jYm, +ja/, f. /--, +rar, +rI, +ja; +jar, +ra, +jYm, +jar/, n. / $+\mathrm{ht},+\mathrm{s},+\mathrm{jY},+\mathrm{ht} ;--,+\mathrm{ra},+\mathrm{jYm},--/$; weak $/+\mathrm{jI} /$. No non-positive. The desinence / $+\mathrm{ht} /$ is replacing: $/ \mathrm{mI}(\mathrm{A}+\mathrm{ht} /$.

(126) dýr "expensive". Stem dýr-. Endings: strong $\mathrm{m} . /--,+\mathrm{s}$ or $+\mathrm{r} s,+\mathrm{Ym}$, +an; +Ir, +r:a, +Ym, +a/, f. /--, +r:ar, +r:I, +a; +ar, +r:a, +Ym, +ar/, n. $/+\mathrm{t}$ or $+\mathrm{rt},+\mathrm{s}$ or $+\mathrm{rs},+\mathrm{Y},+\mathrm{t}$ or $+\mathrm{rt}$; $--,+\mathrm{r}: \mathrm{a},+\mathrm{Ym},--/$. Comparative / $+\mathrm{r}: \mathrm{I} /$ and $/+\operatorname{arI} /$, superlative $/+\mathrm{stYr} /$ or $/+\mathrm{rstYr} /$ and $/+\operatorname{astYr} /$. The desinences $/+\mathrm{rs} /$, $/+\mathrm{r}: \mathrm{a} /, /+\mathrm{r}: \mathrm{ar} /, /+\mathrm{r}: \mathrm{I} /, /+\mathrm{rt} /$ and $/+\mathrm{rstYr} /$ are replacing, e.g. $/ \mathrm{di}(\mathrm{r}+\mathrm{r}: \mathrm{a} /$. In $/ \mathrm{dir}+\mathrm{s} /, / \mathrm{dir}+\mathrm{t} /$, and /dirtstYr/ the Continuant Devoicing Rule (Orešnik 1972b) applies. The endings containing / $\mathrm{r}$ // are provisional, pending the formulation of the quantity rules.

(127) seinn "slow, late". Stem sein-. Endings: strong $\mathrm{m}$. /infix d, $+\mathrm{s},+Y \mathrm{Ym}$, $+a n ;+I r$, infix $\mathrm{g}$ plus $+a,+Y m, \overline{+a /}$, f. $/--$, infix $d$ plus $+a r$, infix $d$ plus $+I$, $+\mathrm{a} ;+\mathrm{ar}$, infix d plus $+\mathrm{a},+\mathrm{Ym},+\mathrm{ar} / \mathrm{n}, \mathrm{n} / \mathrm{t}$ or $+\mathrm{nt},+\mathrm{s},+\mathrm{Y},+\mathrm{t}$ or $+\mathrm{nt} ;$; --, infix $\mathrm{g}$ plus $+\mathrm{a},+\mathrm{Ym},--/$; weak $/+\mathrm{I} /$; comparative /infix d plus $+\mathrm{I} /$; $^{\circ}$ superlative $/+$ astYr/. The desinence / $+\mathrm{nt} /$, which appears in Southern Icelandic only, is replacing: /sei(n+nt/. In /sein+t/ the $T$-Devoicing Rule (Orešnik 1972b) applies in Southern Icelandic.

(128) gamall "old". Two suppletive stems: eld- in the non-positive, gamalelsewhere. Endings: the positive as sub (127), except that the desinence for the nominative/accusative singular neuter is / $+\mathrm{t}$ or $+\mathrm{lt} / ; /+\mathrm{lt} / \mathrm{is}$ replacing: /gama$(\underline{l}+\mathrm{lt} /$. The $\mathrm{T}$-Devoicing Rule (Orešnik 1972b) applies in /gamalt $t$ /. Comparative $/+\mathrm{rI} /$. Superlative / $+\mathrm{stYr} /$, which is replacing: /el $(\underline{d}+\mathrm{stYr} /$. The Vowel syncope Rule and the $u-U m l a u t$ Rule $(/ a / \rightarrow / 0 /$ and $/ a / \rightarrow / Y /)$ apply in the same cases of the positive as in fagur, see no. (122). The unstressed a is "elidible".

(129) mikill "big, great". Three suppletive stems: me- in the superlative, meiin the comparative, mikil- elsewhere; the unstressed i of mikil- is "elidible". The underlying stem mikil- contains a velar, not palatal, $\overline{/ \mathrm{k} /}$, such as occurs in the contracted stem mikl- on the phonetic level. In the non-contracted stem mikil- the Palatalisation Rule (Orešnik MSb) palatalises the velar. The proviso about the $/ \mathrm{k} /$ of the underlying stem mikil- being velar is necessary, because 
there is no Depalatalisation Rule in Modern Icelandic phonology. The Vowel Syncope Rule operates in the same cases of the positive as sub (122), except in the strong accusative singular masculine, where its structural description is not met. Endings of the positive as sub (127), except that the desinence of the strong accusative singular masculine is a replacing $/+n /, /$ miki $(1+n /$, and the desinence of the strong nominative/accusative singular neuter is a replacing $/+d /, /$ miki$(\underline{l}+\mathrm{d} /$. An $\underline{\mathrm{h}}$ is inserted before $\mathrm{kl}$ in the contracted cases by the $\mathrm{H}$-Insertion Rule formulated sub (11) above.

(130) lítill "little". Three suppletive stems: minn- in the non-positive, litl- in the contracted cases of the positive, litil- elsewhere. Endings of the positive as sub (129). Comparative $/+\mathrm{I} /$, superlative $/+\mathrm{stYr} /$. The contracted cases are those in which the Vowel Syncope Rule applies sub (129).

(131) heidinn "heathen". Stem heidin-; $\underline{i}$ is "elidible". Endings: strong m. /--, $+\mathrm{s},+\mathrm{Ym},--;+\mathrm{Ir},+\mathrm{a},+\mathrm{Ym},+\mathrm{a} / \mathrm{f}$. $/--$, +ar, $+\mathrm{I},+\mathrm{a} ;+\mathrm{ar},+\mathrm{a},+\mathrm{Ym},+\mathrm{ar} /$, n. $/+\mathrm{d},+\mathrm{s},+\mathrm{Y},+\mathrm{d} ;--,+\mathrm{a},+\mathrm{Ym},--/$; weak $/+\mathrm{I} /$; comparative $/+\operatorname{arl} /$, superlative / + astYr/. The ending $/+d /$ is replacing: /heidi $(n+d /$. The Vowel syncope Rule applies in the same cases as sub (122), except in the strong accusative singular masculine.

(132) galinn "crazy". (a) Stem gal-. Endings: strong m. /+In, +Ins, +dYm, +In; +dir , +Ina, +dYm, +da/, f. / In, +Inar, +InI, +da; +dar, +Ina, +dYm, $+\operatorname{dar} /$, n. / $+\mathrm{Id},+\mathrm{InS},+\mathrm{dY},+\mathrm{Id} ;+\mathrm{In},+\mathrm{Ina},+\mathrm{dYm},+\mathrm{In} /$; weak /+dI/; comparative $/+$ darl $/$, superlative $/+d a s t Y r /$. The $u$-Umlaut Rule $(/ \mathrm{a} / \rightarrow / 0 /)$ applies in the same cases as sub (122), except in the strong nominative singular feminine and nominative/accusative plural neuter. (b) Two suppletive stems: gald- in the contracted cases, galin- elsewhere. (The contracted cases are those in which the Vowel Syncope Rule applies sub (129) plus the cases of the non-positive.) Endings as sub (131). The $u-U m l a u t$ Rule $(/ a / \rightarrow / 0 /)$ applies in the same cases as sub (122), except in the strong nominative singular feminine and nominative/. accusative plural neuter.

(133) allur "all". Stem all-. Endings as sub (121); no non-positive, no weak forms. The $u-U m l a u t$ Rule $(/ a / \rightarrow / 0 /)$ applies in the same cases as sub (122). A phonological rule deletes the $/ \mathrm{d} /$ of the stem before the desinence $/+\mathrm{t} /$ or $/+1 \mathrm{t} /:$ allt $[\mathrm{alt}]$. The rule can be formulated as follows:

\section{$\underline{\text { D-Deletion Rule }}$}

$$
/ \mathrm{d} / \rightarrow \varnothing / \ldots \mathrm{c}\{\mathrm{t}, \mathrm{d}, \mathrm{n}\}
$$

I. e. any /d/ is deleted if immediately followed by a consonant and $\underline{t}$ or $\underline{d}$ or $\underline{n}$. - Examples: gjarnt $\left[\dot{g}_{j} a n t, \xi_{j} a n t\right]$, fallna. I cannot explain the lack of $/ \bar{d} /$ in the gen. sg. alls, karls. Cf. gen. sg. gulls [ĝYdls] of gull, without the loss of $/ d /$. 
(134) gódur "good". Three suppletive stems: bet- in the non-positive, go- in the nominative/accusative singular neuter, god- elsewhere. Endings of the positive as sub (121), except that the desinence of the nominative/accusative singular neuter is $/+\mathrm{ht} /$. Comparative $/+\mathrm{rI} /$, superlative $/+\mathrm{stYr} / . /+\mathrm{stYr} /$ is a replacing ending: / $\underline{\text { ee}} \underline{t}+\mathrm{stYr} /$.

(135) gladdur "gladdened". Stem gladd-. Endings as sub (121), except that the desinence of the nominative/accusative singular neuter is a replacing / + ht/:/gla$(\underline{d d}+h t /$. The $u-U m l a u t$ Rule $(/ a / \rightarrow / 0 /)$ applies in the same cases as sub (122).

(136) brattur "steep". Stem bratt-. Endings as sub (121), except that there is no desinence in the nominative/accusative singular neuter. The u-Umlaut Rule $(/ a / \rightarrow / 0 /)$ applies in the same cases as sub (122).

(137) vondur "bad, evil". Two suppletive stems: ver- in the non-positive, vondelsewhere. Endings of the positive as sub (121), except that the desinence of the nominative/accusative singular neuter is a replacing $/+t /$ or - in Southern Icelandic only - / nt $/:$, von $(\underline{d}+t /, /$ volnd $+n t /$. In / vont/ the T-Devoicing Rule (Orešnik 1972b) applies in Southern Icelandic. Comparative / $+\mathrm{r}: \mathrm{I} /$, replacing: $/ \mathrm{ve}(\mathrm{r}+\mathrm{r}: \mathrm{I} /$. Superlative / + stYr or + rstYr/. In /ver+stYr/ the Continuant Devoicing Rule (Orešnik 1972b) applies. In /ve $(\underline{r}+\mathrm{rstYr} / \overline{\mathrm{r}}$ the desinence is replacing. The ending $/+\mathrm{r}: \mathrm{I} /$ is provisional, pending the formulation of the quantity rules.

(138) einn "one, alone". Stem ein-. Endings as sub (127), with two exceptions: (1) the desinence of the strong accusative singular masculine is not only $/+a n /$, but also /infix $d /$, with a differentiation in meaning and function, cf. Einarsson 1945:65. (2) The desinence of the nominative/accusative singular neuter is a replacing / $+h t /:$ /ei $(n+h t /$. The fact that the desinence is $/+h t /$ rather than $/+t /$ is a measure of the irregularity of the paradigm. No non-positive.

(139) annar "other". Two suppletive stems: aer- in the contracted cases, annarelsewhere. The following are the contracted cases: dative singular masculine, nominative plural masculine, dative plural, accusative plural masculine, accusative singular feminine, nominative/accusative plural feminine, dative singular neuter. Endings as sub (122), except that the desinence of the accusative singular masculine is a replacing $/+n /$, / $\underline{a n n a}(\underline{r}+n /$, and the desinence of the nominative/accusative singular neuter is a replacing $/+d /$, /anna $(\underline{r}+d /$. No weak forms, no non-positive. The u-Umlaut Rule $(/ \mathrm{a} / \rightarrow / \ddot{\mathrm{o}} /$ and $/ \overline{\mathrm{a} / \rightarrow} / \mathrm{Y} /)$ applies in the same case forms as sub (122).

(140) dasakur "tired". (a) Stem dasad-. Endings of the positive as sub (121), except that there is no ending in the strong nominative/accusative singular neuter. Comparative $/+\mathrm{rI} /$, superlative $/+$ astYr $/$. The $u$-Umiaut Rule $(/ \mathrm{a} / \rightarrow / \ddot{0} /$ and $/ \mathrm{a} / \rightarrow / \mathrm{Y} /$ ) applies in the same cases as sub (122). (b) Stem das-. Endings: strong $\mathrm{m}$. / $+\mathrm{adYr}$, +ads, +YdYm, +adan; +adIr, +adra, +YdYm, +ada/, f. /+Yd, +adrar, +adrI, +ada; +adar, +adra, +YdYm, +adar/, n. /+ad, +ads, +YdY, +ad; $+\mathrm{Yd},+\mathrm{adra},+\mathrm{YdYm},+\mathrm{Yd} /$; weak $/+\mathrm{adI} /$. Comparative $/+\mathrm{adrI} /$. Superlative $/+\mathrm{ad}-$ astYr, +adasts, +YdYstYm, +adastan/ etc. The u-Umlaut Rule $(/ a / \rightarrow / 0 /)$ applies in the same case forms as sub (122). 
(141) nokkur "some". (I) Stem nokkur-; u is "elidible". Endings as sub (122), except that the ending of the accusative singular masculine is $/+n /$ or $/+\mathrm{dn} /$ and the ending of the nominative/accusative singular neuter is $/+\mathrm{t} /$ or a replacing

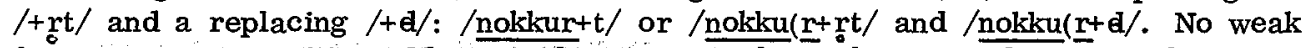
forms, no non-positive. The Vowel syncope Rule applies as sub (129). The D-Insertion Rule, formulated sub (12), applies in /nokkur+n/. In /nokkur+t/ and /nokkur + s/ the Continuant Devoicing Rule (Orešnik 1972b) applies. (II) Stem nokkur-; $\underline{\text { u }}$ is not "elidible". The rest as under (I).

(142) hvass "keen". Stem hvass-. Endings as sub (121), except that the strong nominative singular masculine and the strong genitive singular masculine/neuter have no desinence. The $u-U m l a u t ~ R u l e ~(/ a / \rightarrow / o /)$ applies in the same cases as sub (122).

(143) fús "eager". Stem fús-. Endings as sub (121), except that there is no ending in the strong nominative singular masculine, and that the desinence of the strong genitive singular masculine/neuter is a replacing $/+\mathrm{s}: /: / \underline{\mathrm{fu}}(\underline{\mathrm{s}}+\mathrm{s}: /$. The ending / $+\mathrm{s}: /$ is provisional, pending the formulation of the quantity rules.

(144) vor "our". Stem vor-. Endings as sub (126), except that the desinence of the accusative singular masculine is $/+n /$ or $/+d n /$. No weak forms, no non-positive. The D-Insertion Rule, formulated sub (12), applies in /vor $+n /$.

(145) audugur "wealthy". Stem audug-. Endings as sub (121), except that (1) the desinence of the strong genitive singular masculine/neuter is either $/+s$ / (in which case the Continuant Devoicing Rule (Orešnik 1972b) changes the stem final $/ q /$ to $/ x /$ ) or a replacing / $/ x s /:$ /audu $(g+x s /$. (2) The desinence of the strong nominative/accusative singular neuter is either $/+\mathrm{t} /$ (in which case the Continuant Devoicing Rule applies) or a replacing $/+x t /: / a d u(g+x t /$. Before /I/-initial desinences the stem final $/ q /$ is palatalised to $/ \mathrm{j} /$ by the Palatalisation Rule (Orešnik MSb) and the vowel $\underline{u}$ is diphthongised to an $\underline{i}$-diphthong.

(146) margur "many a". Three suppletive stems: fle- in the superlative, fleiin the comparative, marg- elsewhere. Endings of the positive as sub (121), except that the desinence of the strong nominative/accusative singular neuter is a replacing $/+\mathrm{rt} /: / \mathrm{ma}(\mathrm{rg}+\mathrm{rt} /$. Comparative $/+\mathrm{rI} /$, superlative $/+\mathrm{stYr} /$. The $\mathrm{u}-\mathrm{Um}-$ laut Rule $(/ \mathrm{a} / \rightarrow / \bar{o} /)$ applies in the same cases as sub (122) in the positive.

(147) eigin "own". Stem eigin-. Indeclinable except in the nominative/accusative singular neuter, where the desinence is a replacing $/+d /:$ eigi(n+ $+\mathrm{d} /$. No weak forms, no non-positive.

andvaka "sleepless". Indeclinable.

rennandi "running". Indeclinable.

(150) evrópskur "European". Stem evrópsk-. Endings as sub (121), except that the strong nominative/accusative singular neuter ends in $/+t$ or $+s t /$. Before the 
desinence $/+\mathrm{t} /$ the stem final $\underline{\mathrm{k}}$ is deleted by a phonological rule that will not be formulated here. The desinence / $+\mathrm{t} /$ is replacing: /evrops $(\underline{k}+\mathrm{t} /$. The Palatalisation Rule (Orešnik MSb) applies before /I/-initial desinences.

(151) fraegur "famous". Stem fraeg-. Endings of the positive as sub (145). Comparative / + arI/ and / $+\mathrm{rI} /$. Superlative $/+$ astYr/ and $/+$ stYr or $+\mathrm{xstYr} /$. In /fraeg+stYr/ the Continuant Devoicing Rule (Orešnik 1972b) applies. The desinence / $\mathrm{xstY}$ / is replacing: /frae (g+xstYr/. Before /I/-initial case endings the Palatalisation Rule (Orešnik $\overline{\mathrm{MSb}}$ ) applies, changing the stem final $/ \mathrm{q} /$ to $/ \mathrm{j} /$.

\section{Comparison of Adverbs}

(152) fallega "beautifully". Stem fallega-. Endings: positive $/--/$, comparative $/+r /$, superlative $/+$ st $/$.

(153) fljótt "quickly". Stem fljót-. Endings: positive /+ht/ (replacing), comparative $\overline{/+\mathrm{ar} /}$, superlative /+ast/.

(154) langt "long (of distance)". Two suppletive stems: leng- in the non-positive, lang- elsewhere. Endings: positive $/+\mathrm{t} /$ or $/+\hbar \mathrm{t} /$, comparative $/+\mathrm{ra} /$, superlative $/+$ st $/$. In the representation / lang+t/first the $g$ is deleted between $/ m /$ and $/ t /$ by a rule discussed in Orešnik MSb, fn. 2 , and then $/ \mathrm{m} /$ is devoiced - in Southern Icelandic only - by the T-Devoicing Rule (Orešnik 1972b). The Southern Icelandic desinence $/+\dot{m} \mathrm{t} /$ is replacing: / $\underline{\mathrm{la}}(\mathrm{ng}+\mathrm{h} \mathrm{t} /$. In $/$ leng+st/ the segment $/ \mathrm{g} / \mathrm{is}$ deleted between $/ \mathrm{m} /$ and $/ \mathrm{s} /$ by the above mentioned rule.

(155) lengi "long (of time)". Stem leng-. Endings: positive $/+\mathrm{I} /$, comparative $/+\mathrm{Yr} /$, superlative / $+\mathrm{st} /$. In the representation /leng+st/ the segment /g/ is deleted between $/ \mathrm{m} /$ and $/ \mathrm{s} /$ as sub (154). The Palatalisation Rule (Orešnik MSb) palatalises the $/ \& /$ of the positive lengi to $/ g_{j} /$, and $/ \mathfrak{m} /$ is palatalised to $/ \tilde{n} /$.

(156) hátt "loudly". Two suppletive stems: hae- in the non-positive, há- elsewhere. Endings: positive $/ \mathrm{ht} /$, comparative $/ \mathrm{tr}: \mathrm{a} /$, superlative $/+\mathrm{st} /$. The ending $/+\mathrm{r}: \mathrm{a} /$ is provisional, pending the formulation of the quantity rules.

(157) austur "to/in the east". Stem aust-. Endings: positive $/+\mathrm{Yr} /$, comparative $/+$ ar/, superlative /+ast/.

(158) oft "often". Stem oft-. Endings: positive $/--/$, comparative $/+a r /$, superlative /+ast/.

(159) sjaldan "seldom". Stem sjaldan-; the unstressed a is "elidible". Endings: positive $\frac{T /-1}{\text {, }}$ comparative $/+a r /$, superlative $/+$ ast/. The Vowel Syncope Rule applies in the non-positive, for which reason the formulation of the rule has to be expanded to include non-positives of adverbs. (This category is by inadvertence not mentioned in the formulation of the rule in Orešnik MSc). 
(160) fjarri "far away". Two suppletive stems: firr- in the non-positive, fjarrielsewhere. Endings: positive $/--/$, comparative $/--/$, superlative $/+$ st or + rst $/$. In the representation /firtst/ the Continuant Devoicing Rule (Orešnik 1972b) applies and devoices $/ \mathrm{r} /$ to $/ \mathrm{r} /$. The alternative ending $/+\mathrm{r}_{0} s t /$ is replacing: $/ \mathrm{fi}(\mathrm{r}+$ rst/.

(161) fjaer, fjaerri "far away". Stem fjaer-. Endings: positive /-- and $+r: I /$, comparative / $/$, superlative $/+$ st or $+r s t /$. In the form /fjaer + st/ the Continuant Devoicing Rule (Orešnik 1972b) applies, yielding $/ \mathrm{r} /$. The endings $/+\mathrm{r}: \mathrm{I} /$ and /+rst/ are replacing: /fjae $(\underline{r}+r: I /$, /fjae $(\underline{r}+r s t /$. The ending / $+r: I /$ is provisional, pending the formulation of the quantity rules.

(162) naer, naerxi "near". Stem nae-. Endings: positive $/+r$ and $+r: I /$, comparative $\overline{/+r /}$, superlative $/+s t /$. The ending $/+r: I /$ is provisional, pending the formulation of the quantity rules.

(163) sudur "to the south". Three suppletive stems: syd- in the superlative, sunn- in the comparative, sud- elsewhere. Endings: positive $/+\mathrm{Yr} /$, comparative $\overline{/+\mathrm{ar}} /$, superlative $/+\mathrm{st} /$.

(164) vel "well". Two suppletive stems: bet- in the non-positive, vel- elsewhere. Endings: positive $/--/$, comparative $/+\mathrm{Yr} /$, superlative $/+\mathrm{st} /$. The ending /+st/ is replacing: / $\mathrm{be}(\mathrm{t}+\mathrm{st} /$.

(165) illa "badly". Two suppletive stems: vĕr- in the non-positive, illa- elsewhere. Endings: positive and comparative $\overline{l--1}$, superlative $/+$ st or $+\overline{\text { rst }} /$. The Continuant Devoicing Rule (Orešnik 1972b) applies in /ver+st/. The desinence /+rst/ is replacing: / $\underline{\text { ve }}(\underline{\mathrm{r}}+\mathbf{r}$ st/.

(166) lítid "little". Two suppletive stems: minn- in the non-positive, lítid- elsewhere. Endings: positive $/--/$, comparative $\overline{/+a} /$, superlative $/+$ st $/$.

(167) lítt "little". Three suppletive stems: minn- in the superlative, mid- in the comparative, lift- in the positive. Endings: positive $/--/$, comparative $/+\mathrm{Yr} /$, superlative $/+$ st $/$.

Note. I am aware that the above-mentioned adverbs fallega, illa, and lítid can be analysed into falleg-a. (cf. falleg-ur), ill-a (cf. ill-ur), and líti(l+d (cf. lítill), respectively, but I believe that the adverbs fallega, illa, and lítid are independent lexical items, only related to the respective adjectives by rules of historical, not synchronic, word formation.

\section{REFERENCES}

Einarsson, Stefán: Icelandic. Grammar. Texts. Glossary. Baltimore, 1945. I have used the corrected fifth printing of 1967. 
Orešnik, Janez: "On the Epenthesis Rule in Modern Icelandic". Arkiv för nordisk filologi 87 (1972) 1-32. - Referred to as Orešnik 1972a.

---, "Four Modern Icelandic devoicing rules". Linguistica 12 (1972) 137-56. Referred to as Orešnik 1972b.

---, "Old Icelandic Consonant Lengthening Rule and Modern Icelandic infixation of /d/". Linguistica 13 (1973) 229-61.

---, "Modern Icelandic u-Umlaut from the descriptive point of view". Forthcoming. - Referred to as Orešnik MSa.

---, "On the Modern Icelandic Palatalisation Rule". Forthcoming. - Referred to as Orešnik MSb.

---, "The Modern Icelandic Epenthesis Rule revisited". Forthcoming. - Referred to as Orešnik MSc.

---, "Uber die Lautalternationen im neuisländischen Typus veggur". Forthcoming. - Referred to as Orešnik MSd.

\section{Notes}

1 My thanks are due to Miss Margaret G. Davis, who has corrected my English. 2

Here and below the endings are listed in the following order: nominative, genitive, dative, accusative, first of the singular, then, after a semicolon, of the plural.

3

The u-Umlaut Rule comprises a number of rules of the form, $/ a / \rightarrow / 0 /$, $/ a / \rightarrow / Y /, / \ddot{o} / \rightarrow / a /$, and $/ Y / \rightarrow / a /$. The rule is discussed at length in Orešnik MSa. It is morphological, i.e. it applies, whenever certain phonological conditions obtain, in certain grammatical forms, e.g. in the dative plural of nouns.

4 Whether the infix is / $d /$ or /d:/ depends on the formulation of the quantity rules. I have here arbitrarily opted for $/ d /$.

Povzetek

FLEKSIJA NOVOISLANDSKIH SAMOSTALNIKOV, PRIDEVNIKOV IN PRISLOVOV

članek je seznam novoislandskih samostalnikov, pridevnikov in prislovov, razčlenjenih na osnove in končnice; vključena je tudi sklanjatev postpozitivnega določnega člena. Pri vsaki besedi je navedeno, katera fonološka pravila delujejo v izpeljavi njenih oblik. Nova fonološka pravila so obravnavana pri naslednjih besedah: (3), (11), (12) in (133). V seznamu je avtor uporabil neko teoretično inovacijo, namreč t.i. nadomeščujoče končnice. Te se ne dodajajo za zadnjim segmentom osnove, kot končnice na splošno, temveč nadomeščajo zadnji segment (zadnje segmente) osnove. Več o nadomeščujočih končnicah $\mathrm{v}$ uvodu. 